\title{
Comparison of inorganic nitrogen uptake dynamics following snowmelt and at peak biomass in subalpine grasslands
}

\author{
N. Legay ${ }^{1}$, F. Grassein ${ }^{2}$, T. M. Robson ${ }^{3}$, E. Personeni ${ }^{4}$, M.-P. Bataillé ${ }^{4}$, S. Lavorel ${ }^{1}$, and J.-C. Clément ${ }^{1}$ \\ ${ }^{1}$ Laboratoire d'Ecologie Alpine, UMR CNRS 5553, Université Joseph Fourier, Grenoble, France \\ ${ }^{2}$ Institute of Plant Science, University of Bern, Altenbergrain 21, 3013 Bern, Switzerland \\ ${ }^{3}$ Department of Biosciences, Plant Biology, P.O. Box 65, 00014 University of Helsinki, Finland \\ ${ }^{4}$ INRA, UMR950, EVA, Ecophysiologie Végétale, Agronomie et nutritions N, C, S, Université de Caen Basse-Normandie, \\ Caen, France
}

Correspondence to: N. Legay (nicolas.legay@gmx.com)

Received: 8 April 2013 - Published in Biogeosciences Discuss.: 29 May 2013

Revised: 2 October 2013 - Accepted: 27 October 2013 - Published: 25 November 2013

\begin{abstract}
Subalpine grasslands are highly seasonal environments and likely subject to strong variability in nitrogen $(\mathrm{N})$ dynamics. Plants and microbes typically compete for $\mathrm{N}$ acquisition during the growing season and particularly at plant peak biomass. During snowmelt, plants could potentially benefit from a decrease in competition by microbes, leading to greater plant $\mathrm{N}$ uptake associated with active growth and freeze-thaw cycles restricting microbial growth. In managed subalpine grasslands, we expect these interactions to be influenced by recent changes in agricultural land use, and associated modifications in plant and microbial communities. At several subalpine grasslands in the French Alps, we added pulses of ${ }^{15} \mathrm{~N}$ to the soil at the end of snowmelt, allowing us to compare the dynamics of inorganic $\mathrm{N}$ uptake in plants and microbes during this period with that previously reported at the peak biomass in July. In all grasslands, while specific shoot $\mathrm{N}$ translocation (per $\mathrm{g}$ of biomass) of dissolved inorganic nitrogen (DIN) was two to five times greater at snowmelt than at peak biomass, specific microbial DIN uptakes were similar between the two sampling dates. On an area basis, plant communities took more DIN than microbial communities at the end of snowmelt when aboveground plant biomasses were at least two times lower than at peak biomass. Consequently, inorganic $\mathrm{N}$ partitioning after snowmelt switches in favor of plant communities, allowing them to support their growing capacities at this period of the year. Seasonal differences in microbial and plant inorganic $\mathrm{N}$-related dynamics were also affected by past (terraced vs. unterraced) rather than current (mown vs. unmown) land use.
\end{abstract}

In terraced grasslands, microbial biomass $\mathrm{N}$ remained similar across seasons, whereas in unterraced grasslands, microbial biomass $\mathrm{N}$ was higher and microbial $\mathrm{C}: \mathrm{N}$ lower at the end of snowmelt as compared to peak biomass. Further investigations on microbial community composition and their organic $\mathrm{N}$ uptake dynamics are required to better understand the decrease in microbial DIN uptake.

\section{Introduction}

Nutrient availability and the ability to take up nitrogen $(\mathrm{N})$ efficiently are critical plant features in ecosystems (Kaye and Hart, 1997; Lipson and Nasholm 2001; Harrison et al., 2008). Plants preferentially absorb inorganic $\mathrm{N}$, though plant organic $\mathrm{N}$ uptake has also been demonstrated (Harrison et al., 2007). In contrast, soil microbes, depending on their turnover status, can be considered as $\mathrm{N}$ sinks or sources for dissolved organic (e.g. amino acids) and inorganic $\mathrm{N}$ (e.g. nitrate $\left(\mathrm{NO}_{3}^{-}\right)$and ammonium $\left.\left(\mathrm{NH}_{4}^{+}\right)\right)$in soils. This means that plant $\mathrm{N}$ uptake must operate in a dynamic relationship with that of soil microbes, which can both compete for and produce $\mathrm{N}$ forms (Schmidt et al., 2007; Van der Heijden et al., 2008).

Such dynamics are particularly critical in cold ecosystems (e.g. tundra and alpine meadows), which are characterized by slow $\mathrm{N}$ mineralization rates (Bardgett et al., 2007). In alpine ecosystems, soil microbes are strongly influenced by environmental conditions and particularly seasonal 
variability (Mancinelli, 1984). Microbial pool size fluctuates during repeated freeze-thaw cycles (Schimel and Clein, 1996) and soil microbial activities and phylogenetic composition change significantly over such short timescales (Baptist et al., 2008) that can impact ecosystem processes such as litter decomposition (Zhu et al., 2013). These freeze-thaw cycles, as well as decreases of soluble organic nutrient concentrations, are known to be main factors leading to a microbial crash, a drastic decrease in microbial biomass (Jaeger et al., 1999; Jefferies et al., 2010; Edwards and Jefferies, 2013; Zhu et al., 2013), or induce microbial quiescence, which is a dormant state in stressful environments (Malik and Smith, 2006). Such seasonal variability can influence plant-microbe relationships, affecting plant $\mathrm{N}$ uptake, microbial activities, and the composition and biomass of microbial communities (Jaeger et al., 1999; Jefferies et al., 2010; Larsen et al., 2012). It is well known that plants and microbes compete for $\mathrm{N}$ acquisition mainly during the growing season and particularly during the peak of plant productivity. For instance, Bardgett et al. (2002) showed that, early in the growing season in May, the dominant graminoid on a mountain plateau obtained $\mathrm{N}$ either from stored reserves or from uptake through its active roots over the winter. By June, this plant switched to $\mathrm{N}$ that was surplus to microbial requirements as mineralization rates increased in parallel with aboveground growth and soil $\mathrm{N}$ concentrations. At Niwot Ridge, an alpine environment, Jaeger et al. (1999) explained seasonal variations in microbial $\mathrm{N}$ immobilization by freeze-thaw cycles which restricted microbial growth. Such seasonal shifts in plantmicrobe relationships are suspected to have important repercussions on nutrient cycling and ecosystem functioning (Lipson and Nasholm, 2001). As yet, evidence for these dynamics is largely limited to alpine and high-latitude ecosystems; however it could occur in a broader array of cold ecosystems, including subalpine grasslands where climatic conditions are slightly more favorable for plant growth with a longer growing season and higher mean temperatures, but more freezethaw events (Saccone et al., 2013).

In subalpine grasslands, like in many terrestrial ecosystems (Kaye and Hart, 1997), $\mathrm{N}$ is the most limiting nutrient to the net primary productivity, and therefore also limits other trophic levels. $\mathrm{N}$ inputs are low (from $\mathrm{N}$ fixation, snow or atmospheric depositions) when human activities are absent or limited (Clément et al., 2012). This limitation might be reinforced in subalpine grasslands since the mineralization rate of soil organic matter is severely constrained by climatic conditions (Saccone et al., 2013). In managed grasslands, interactions among plants and microbes, and their implications for nutrient cycling are also influenced by current and past human activities (Steenwerth et al., 2000; Robson et al., 2007; Strickland et al., 2010). In European mountains, including the French Alps, agricultural management has often converted naturally forested landscapes to terraced crops and semi-natural grasslands (Girel et al., 2010). Today, landscapes include a diversity of grassland communities whose botanical and functional composition depend on past (terraced vs. unterraced) and current (manuring, mowing) land use (Quétier et al., 2007a). Since the 1950s, decreased management intensity has strongly affected ecosystem functioning by changing plant-community functional composition towards more conservative nutrient use strategies, particularly tussock grasses (Quétier et al., 2007a), thereby impacting ecosystem services such as grassland agronomic and cultural values (Lavorel et al., 2011; Schirpke et al., 2012). These functional changes also include decreased $\mathrm{N}$ availability and net $\mathrm{N}$ mineralization (Robson et al., 2007), with a parallel decrease in microbial activities, and an increase in soil C: $\mathrm{N}$ ratio and fungal:bacteria ratio (Zeller et al., 2000; Robson et al., 2007). Such a decrease in soil $\mathrm{N}$ availability could interfere with seasonal patterns of interactions between plant and microbial communities for the acquisition of this limiting resource.

Our study was conducted in the Lautaret Pass area (Central French Alps) where previous studies have shown that traditional grassland management including mowing and manuring increased plant-available $\mathrm{N}$ and soil $\mathrm{N}$ pools during the growing season (June-August) (Robson et al., 2007). A previous isotopic pool-dilution experiment during peak biomass and flowering (July 2005) observed in more intensively managed grasslands that plants exerted a greater control over $\mathrm{N}$ cycling than microorganisms, and that a greater $\mathrm{N}$ uptake by plants and microbes stimulated soil $\mathrm{N}$ availability, allowing nutrients to be more readily returned to the soil (Robson et al., 2010). Yet, the literature on $\mathrm{N}$ cycling in mountain ecosystems describes the snowmelt period as a "key moment" for the overall yearly $\mathrm{N}$ budget and in the partitioning of $\mathrm{N}$ resources between plants and microbes (Jaeger et al., 1999; Bardgett et al., 2005). Therefore, the objectives of our study were (i) to determine whether plant and microbes differed in their $\mathrm{N}$ uptake at the end of snowmelt and at peak biomass (Robson et al., 2010); (ii) how management can act on $\mathrm{N}$ uptake of plants and microbes; and (iii) how management and temporal variability mediated $\mathrm{N}$ partitioning between plant and microbial communities in link with $\mathrm{N}$ cycling. We hypothesized that seasonal $\mathrm{N}$ partitioning was due to a decrease in microbial activities (e.g. $\mathrm{N}$ uptake) at the end of snowmelt which allowed plants to fulfill most of their $\mathrm{N}$ needs in the meantime, and thus changed the dynamics of $\mathrm{N}$ fluxes. To determine whether this seasonal $\mathrm{N}$ partitioning occurred and differed across land use types, we quantified the $\mathrm{N}$ pools and fluxes for microbial, plants and soil compartments with ${ }^{15} \mathrm{~N}$ labeling just after snowmelt. We anticipated higher rates of $\mathrm{N}$ uptake by plants in comparison to microbes, and a change in the $\mathrm{N}$ dynamics when compared to the summer (Robson et al., 2010). We also expected that more intensively managed plant communities dominated by fast-growing species would benefit from microbial quiescence (Malik and Smith, 2006) to take up more N than at peak biomass, whereas less intensively managed communities dominated by slow-growing, conservative plant species 
would maintain the same $\mathrm{N}$ uptake rate throughout the growing season.

\section{Materials and methods}

The field site is located in the central French Alps between the village of Villar d'Arêne and the Lautaret Pass $\left(45^{\circ} 02^{\prime} \mathrm{N}\right.$; $6^{\circ} 20^{\prime} \mathrm{E} ; 1650-2000 \mathrm{~m}$ a.s.l.). The climate is subalpine with a strong continental influence. The annual precipitation in 2010 was $954 \mathrm{~mm}$ and mean annual precipitation since 2004 is $956 \mathrm{~mm}$. Based on temperature records from 2004-2010, winters are cold and snowy with a mean temperature of $-6.5^{\circ} \mathrm{C}$ in February, whereas summers are dry with a mean temperature of $13.9^{\circ} \mathrm{C}$ in July. The growing season begins during snowmelt, usually in early May, and continues until late September.

We studied twelve grasslands, representing four combinations of past (terraced vs. unterraced) and present (mown vs. unmown) land uses (Quétier et al., 2007a) (three replicates for each combination). Two types of grasslands were on terraced slopes, the first was mown for hay in early July (mown terraced, MT), and the second was never mown but lightly grazed in early July (unmown terraced, UT). Unterraced grasslands were either still currently mown in early August (mown unterraced, MU) or only very lightly grazed during the seasonal migration of livestock to summer pastures (unmown unterraced, UU). Their abiotic characteristics and plant communities are described in detail in Quétier, Thébault and Lavorel (2007b), and management has been stable at least since measurements began in 2003. Briefly, the dominant vegetation on the two terraced grasslands consists in a mixture of species with exploitative traits (high specific leaf area, leaf nitrogen concentration and relative growth rate) such as Dactylis glomerata, Bromus erectus, Briza media or Sesleria caerula. The plant communities of the two unterraced grasslands are dominated by plant species with conservative traits (low specific leaf area, relative growth rate and high leaf dry matter content), namely Festuca paniculata, Meum athamanticum, Festuca rubra or Carex sempervirens.

The same grassland fields were studied using exactly the same isotope labeling protocol during summer 2005 (Robson et al., 2010).

We made a pool dilution experiment by inoculating all fields with ${ }^{15} \mathrm{~N}$ in order to understand $\mathrm{N}$ competition at the end of the snowmelt period on 17th and 18th May 2010. The period matches the end of snowmelt since all grasslands were still snow covered the week preceding the labeling (personal observations). Moreover, the starting day of the experiment, soils were snow free and waterlogged with soil water contents ranging from 0.39 to $0.56 \mathrm{~g}$ of water per $\mathrm{g}^{-1}$ of soil, values already observed at this same period in other studies at these sites (Robson et al., 2007; Clement et al., 2012). Together, these measurements and observations con- firmed that sampling occurred during the late thaw period as described by Edwards and Jefferies (2013). The soil was inoculated with a solution of ammonium nitrate $\left(\mathrm{NH}_{4}^{+} \mathrm{NO}_{3}^{-}\right)$ $98 \%$ dual-labeled with ${ }^{15} \mathrm{~N}$ to allow a homogenous supply (monitoring) of $\mathrm{N}$ between soil, plants and microbes. A concentration of either 1.2 (MT and UT field types) or $0.8 \mathrm{~g} \mathrm{~m}^{-2}$ (MU and UU field types) of ${ }^{15} \mathrm{~N}\left(6.42 \mu \mathrm{g} \mathrm{N} \mathrm{g}{ }^{-1}\right.$ soil for each fields) was chosen, equivalent of ca. $10 \%$ of the maximum $\mathrm{NH}_{4}^{+} \mathrm{NO}_{3}^{-}$pool $(0-10 \mathrm{~cm})$ at the site. A total of $100 \mathrm{~mL}$ of labeled ${ }^{15} \mathrm{NH}_{4}^{+}{ }^{15} \mathrm{NO}_{3}^{-}$solution was injected across three $40 \times 20 \mathrm{~cm}$ areas within each of the 12 fields. A $4 \mathrm{~mL}$ volume was injected into the soil at $0-5 \mathrm{~cm}$ depth, spaced $2 \mathrm{~cm}$ apart over the delimited area. An alloy nail slightly wider than the syringe needle was used to make a conduit for the needle to enter the soil.

Plant biomass and soil cores were sampled prior to inoculation to obtain zero-time-control ${ }^{15} \mathrm{~N}$ natural abundance measurements. Following inoculation, a time course of ${ }^{15} \mathrm{~N}$ remaining in the $\mathrm{NH}_{4}^{+} / \mathrm{NO}_{3}^{-}$pools was obtained from samples taken after $48 \mathrm{~h}$ and 1 week. These time periods were chosen based on actual in situ soil inorganic $\mathrm{N}$ pools and turn-over rates measured for the same subalpine grasslands at regular intervals from 2004-2005 (Robson et al., 2007), including overwinter measurements (Clement et al., 2012). A sample of aboveground biomass was harvested from $200 \mathrm{~cm}^{2}$ of each inoculated area (three subplots) in all 12 fields, allowing a border to avoid any edge effect. Two soil cores of $4.5 \mathrm{~cm}$ diameter were removed and fresh weight obtained from all three subplots, in the same place as the biomass harvest. One core was used for soil analyses and the other one for root analyses.

Cores for root analyses were carefully dissolved in tepid water and roots were separated by floatation, weighed fresh, then dried $\left(70^{\circ} \mathrm{C}, 72 \mathrm{~h}\right)$ and reweighed. Root cores were weighed before root separation to allow calculation of root density.

Cores for soil analyses were kept on ice in the field and maintained at $4{ }^{\circ} \mathrm{C}$ upon return to the laboratory (within $2 \mathrm{~h}$ ). Soil was passed through a $5.6 \mathrm{~mm}$ sieve to remove roots and stones, to avoid any nitrogen mineralization flush by soil microbes when a mesh of $2 \mathrm{~mm}$ is used (Jones and Willet, 2006), and to determine soil density. Two $10 \mathrm{~g}$ samples of fresh, sieved soil were subsampled, one for $\mathrm{K}_{2} \mathrm{SO}_{4}$ $(0.5 \mathrm{M})$ extraction of mineral $\mathrm{N}$, and the other one for chloroform fumigation and subsequent $\mathrm{K}_{2} \mathrm{SO}_{4}(0.5 \mathrm{M})$ extraction to quantify microbial $\mathrm{N}$. Chloroform fumigation was performed for 7 days (Brookes et al., 1985). Subsamples of $10 \mathrm{~g}$ of sieved soil were shaken mechanically in $50 \mathrm{~mL}$ of $\mathrm{K}_{2} \mathrm{SO}_{4}(0.5 \mathrm{M})$ for $1 \mathrm{~h}$ at $250 \mathrm{rpm}$. $\mathrm{NH}_{4}^{+}$and $\mathrm{NO}_{3}^{-}$were each removed from the $\mathrm{K}_{2} \mathrm{SO}_{4}$ solution using acid-trap diffusion extraction (Stark and Hart, 1996), and prepared for mass spectrometry to determine ${ }^{14} \mathrm{~N}$ and ${ }^{15} \mathrm{~N}$ concentrations of these two $\mathrm{N}$ forms. Soil microbial $\mathrm{N}$ concentrations were calculated as the difference of total $\mathrm{N}$ between unfumigated 
and fumigated soil samples. The ${ }^{14} \mathrm{~N}$ and ${ }^{15} \mathrm{~N}$ contents were estimated for all samples using a direct-combustion mass spectrometer (IRMS, Isoprime, Elementar). A subsample of $\mathrm{K}_{2} \mathrm{SO}_{4}$ soil extracts were analysed by colorimetry (Fiastar 5012 Flow Injection Analyser, Foss Tecator AB, Sweden, following Bowman; Bahnj and Damm, 2003), to provide estimates of $\mathrm{NH}_{4}^{+}$and $\mathrm{NO}_{3}^{-}$concentrations for the mass spectrometry samples.

Aboveground biomass was dried at $65^{\circ} \mathrm{C}$ and weighed to calculate the relative growth rate (RGR) at the community level between each sampling date, and a subsample of green leaf material from non-senescent leaves was removed and ground for ${ }^{15} \mathrm{~N}$ analysis by mass spectrometry.

\section{Data analyses}

All biochemical analyses were performed on pooled samples from three subplots in each field, and replicated across three fields for each land use.

The estimation of the daily ${ }^{15} \mathrm{~N}$ uptake rate from the soil pool by each compartment (plants and microbes) was calculated using the relative proportion of the added ${ }^{15} \mathrm{~N}$ remaining in the soil and in the other compartments over the period from incubation until each sampling date, following the equation described in Stark (2000):

$M_{\mathrm{AB}}=\left(P_{\mathrm{Bt}} * I_{\mathrm{Bt}}\right) /\left(\left(I_{\mathrm{A} 0} *(1--e-k)\right) / k\right)$

, where $k=\ln \left(I_{\mathrm{A} 0} / I_{\mathrm{At}}\right) / t . M_{\mathrm{AB}}$ is the total amount of nutrient (added plus natural isotopes) that flowed from pool $\mathrm{A}$ (source) to pool B (sink) during the incubation period (e.g. $\mathrm{mg} \mathrm{N} \mathrm{kg}{ }^{-1}$ soil); $P_{\mathrm{Bt}}$ is the size of the sink pool (B) at the end of incubation; $\mathrm{I}_{B t}$ the relative amount of isotope, in excess of background, that is found in pool B (sink) at the end of the incubation; $I_{\mathrm{A} 0}$ is the relative amount, in excess of background, that is present in the source pool $\mathrm{A}$ at the beginning of the incubation; $I_{\mathrm{At}}$ is the relative amount of isotope, in excess, that is present in the source pool at the end of the incubation; and $t$ is the length of the incubation time (see Stark 2000 for details).

This method was used to calculate plant and microbial $\mathrm{N}$ uptake rates which both represented a sink pool of ${ }^{15} \mathrm{~N}$ for the source pool of $\mathrm{N}$, namely soil ${ }^{15} \mathrm{~N}$ pool. They were expressed in function of plant or microbial biomasses, named thereafter "specific" $\mathrm{N}$ uptake rate, or expressed per field area, named thereafter "gross" $\mathrm{N}$ uptake rate specifically for microbes.

Gross $\mathrm{N}$ production and consumption rates for $\mathrm{NH}_{4}^{+}$and $\mathrm{NO}_{3}^{-}$were calculated using the isotope dilution equations from Kirkham and Bartholomew (1954; in Stark, 2000):

$$
\text { Gross production rate } \begin{aligned}
(\mathrm{GPR})=\left[\left(P_{0}-P_{t}\right) / t\right] \\
\times\left[\log \left(I_{0} / I_{t}\right) / \log \left(P_{0} / P_{t}\right)\right]
\end{aligned}
$$

Gross consumption rate $(\mathrm{GCR})=\mathrm{GPR}-\left[\left(P_{t}-P_{0}\right) / t\right]$

, where $P_{0}$ and $P_{t}$ are the nutrient concentrations at the beginning and at the end of the incubation, respectively; $I_{0}$ and
It are the relative amounts, in excess, that are present in the nutrient pool at the beginning and at the end of the incubation (at. \% excess), respectively; and $t$ is the length of the incubation time.

To minimize errors during calculation of $\mathrm{N}$ fluxes, we used the $48 \mathrm{~h}$ sampling time, assuming that labeled $\mathrm{N}$ added to the soil could cycle quickly between microbial and plant $\mathrm{N}$ pools. This duration was also chosen in July 2005 to calculate $\mathrm{N}$ fluxes and will therefore allow a comparison with our results. This comparison should be considered with care since microbial recycling of ${ }^{15} \mathrm{~N}$ could potentially occur within $48 \mathrm{~h}$ and led to underestimations of gross cycling rates and microbial $\mathrm{N}$ biomasses which, in addition to inter-annual variability, probably added to seasonal variability. Nevertheless, an incubation time of $48 \mathrm{~h}$ usually prevents the significant recycling of isotope into the source pool (Stark, 2000), in addition to the fact that at our site, microbial activities were low, notably during the winter period (Robson et al., 2007; Clement et al., 2012). The mean monthly temperature for the site at peak biomass was $11.6^{\circ} \mathrm{C}\left( \pm 4.4^{\circ} \mathrm{C}\right)$ in July 2005 and $13.9^{\circ} \mathrm{C}\left( \pm 4.8^{\circ} \mathrm{C}\right)$ in July 2010 . The mean monthly temperatures at snowmelt, i.e. April 2005 and May 2010 , were $1.2^{\circ} \mathrm{C}\left( \pm 3.1^{\circ} \mathrm{C}\right)$ and $1.9^{\circ} \mathrm{C}\left( \pm 3.2^{\circ} \mathrm{C}\right)$, respectively. Therefore, we argue that, even though both sampling sessions did not occur within the same year, they were contrasted enough (i.e. the end of the snowmelt in May 2010 vs. the peak of aboveground biomass in July 2005) to be considered as different seasons and to produce drastically different ecosystem functioning and $\mathrm{N}$ cycling. Furthermore, there were no extreme climatic events over the intervening period, and both 2005 and 2010 can be considered within the range of average climate conditions.

In all grasslands studied at the end of snowmelt, the effects of past (terraced vs. unterraced) and current (mown vs. unmown) land use on biomass, $\mathrm{N}$ concentration and $\mathrm{N}$ flux in each compartment were tested using a two-way ANOVA. A Tukey's studentized range (HSD - Honest Significant Differences) test was used to examine a posteriori differences among land use means. Using the raw data set from Robson et al. (2010), the effect of time (end of snowmelt vs. peak biomass), past and current land use were tested with a three-way ANOVA. Finally, to investigate seasonal variations, a Kruskall-Wallis test of pair-wise comparisons across land use types was used to test whether there was evidence for seasonal variations between May and July. Where necessary, data were transformed to better comply with the criteria of normality and homoscedasticity required for analyses. All analyses were performed in JMP 7.0 (SAS Institute, Cary, NC). 
Table 1. Effect of past (terraced vs. unterraced) and current (mown vs. unmown) land uses on plant biomass, $\mathrm{N}$ pools and fluxes of soil, plant and microbial communities at the end of snowmelt in May 2010. Values are results of ANOVAs $(F)$ and significance $(* * * p<0.001$, ** $p<0.01,{ }^{*} p<0.05$, ns: not significant).

\begin{tabular}{|c|c|c|c|c|c|c|}
\hline & \multicolumn{2}{|c|}{ Past land use } & \multicolumn{2}{|c|}{ Current land use } & \multicolumn{2}{|c|}{ Past $\times$ current } \\
\hline & $F$ & $p$ & $F$ & $p$ & $F$ & $p$ \\
\hline \multicolumn{7}{|l|}{ (a) Soil N pools } \\
\hline $\mathrm{N}-\mathrm{NO}_{3}^{-}\left(\mu \mathrm{g} \mathrm{Ng}^{-1}\right.$ soil $)$ & 32.70 & $* * *$ & 8.10 & * & 3.90 & ns \\
\hline $\mathrm{N}-\mathrm{NO}_{3}^{-}\left(\mathrm{mg} \mathrm{Nm}^{-2}\right.$ area $)$ & 34.70 & $* * *$ & 9.20 & * & 4.90 & $\mathrm{~ns}$ \\
\hline $\mathrm{N}-\mathrm{NH}_{4}^{+}\left(\mu \mathrm{g} \mathrm{Ng}^{-1}\right.$ soil $)$ & 1.00 & ns & 0.72 & $\mathrm{~ns}$ & 6.93 & * \\
\hline $\mathrm{N}-\mathrm{NH}_{4}^{+}\left(\mathrm{mgNm}^{-2}\right.$ area $)$ & 0.17 & ns & 0.28 & $\mathrm{~ns}$ & 6.53 & $*$ \\
\hline $\mathrm{N}-\mathrm{NH}_{4}^{+} / \mathrm{N}^{-} \mathrm{NO}_{3}^{-}$ratio & 43.63 & $* * *$ & 10.37 & $*$ & 0.22 & $\mathrm{~ns}$ \\
\hline \multicolumn{7}{|l|}{ (b) Microbial N pools } \\
\hline Microbial biomass $\mathrm{N}\left(\mu \mathrm{g} \mathrm{Ng}^{-1}\right.$ soil $)$ & 0.50 & $\mathrm{~ns}$ & 0.02 & ns & 1.57 & ns \\
\hline Microbial biomass $\mathrm{N}\left(\mathrm{g} \mathrm{N} \mathrm{m}^{-2}\right.$ area) & 0.01 & $\mathrm{~ns}$ & 0.07 & $\mathrm{~ns}$ & 1.93 & $\mathrm{~ns}$ \\
\hline Microbial C/N & 78.24 & $* * *$ & 1.71 & $\mathrm{~ns}$ & 5.95 & * \\
\hline \multicolumn{7}{|l|}{ (c) Plant N pools } \\
\hline Aboveground plant ( $\mathrm{mg} \mathrm{Ng}^{-1}$ biomass) & 1.80 & ns & 0.87 & ns & 0.23 & ns \\
\hline Aboveground plant $\left(\mathrm{g} \mathrm{Nm}^{-2}\right.$ area $)$ & 22.21 & $* *$ & 3.11 & ns & 1.27 & $\mathrm{~ns}$ \\
\hline Root ( $\mathrm{mg} \mathrm{Ng}^{-1}$ biomass) & 20.95 & $* *$ & 0.24 & ns & 1.81 & $\mathrm{~ns}$ \\
\hline $\operatorname{Root}\left(\mathrm{g} \mathrm{Nm}^{-2}\right.$ area $)$ & 0.97 & $\mathrm{~ns}$ & 3.79 & $\mathrm{~ns}$ & 0.88 & $\mathrm{~ns}$ \\
\hline \multicolumn{7}{|l|}{ (d) Plant biomass } \\
\hline Aboveground plant biomass ( $\mathrm{g} \mathrm{m}^{-2}$ area) & 11.42 & $* *$ & 1.30 & ns & 0.15 & $\mathrm{~ns}$ \\
\hline Relative growth rate $\left(\mathrm{mgg}^{-1} \mathrm{~d}^{-1}\right)$ & 13.91 & * & 2.38 & ns & 4.715 & $\mathrm{~ns}$ \\
\hline Root density ( $\mathrm{g} \mathrm{m}^{-2}$ area) & 53.68 & $* * *$ & 0.65 & $\mathrm{~ns}$ & 11.47 & $* *$ \\
\hline \multicolumn{7}{|l|}{ (e) Soil N flux } \\
\hline Gross $\mathrm{N}^{-\mathrm{NO}_{3}^{-}}$consumption rate $\left(\mu \mathrm{g} \mathrm{Ng}{ }^{-1}\right.$ soil $\cdot$ day $\left.^{-1}\right)$ & 0.60 & $\mathrm{~ns}$ & 0.72 & $\mathrm{~ns}$ & 1.35 & ns \\
\hline Gross $\mathrm{N}^{-\mathrm{NO}_{3}^{-}}$consumption rate $\left(\mathrm{mg} \mathrm{Nm}^{-2} \mathrm{day}^{-1}\right)$ & 1.24 & ns & 0.41 & $\mathrm{~ns}$ & 1.48 & $\mathrm{~ns}$ \\
\hline Gross $\mathrm{N}-\mathrm{NH}_{4}^{+}$consumption rate $\left(\mu \mathrm{g} \mathrm{Ng}^{-1}\right.$ soil $\cdot$ day $\left.^{-1}\right)$ & 9.99 & * & 0.42 & $\mathrm{~ns}$ & 1.1 & $\mathrm{~ns}$ \\
\hline Gross $\mathrm{N}-\mathrm{NH}_{4}^{+}$consumption rate $\left(\mathrm{mgNm}^{-2} \mathrm{day}^{-1}\right)$ & 12.18 & * & 0.15 & ns & 1.02 & $\mathrm{~ns}$ \\
\hline \multicolumn{7}{|l|}{ (f) Microbial $\mathrm{N}$ uptake } \\
\hline Specific $\mathrm{N}$ uptake rate per $\mathrm{g}$ soil $\left(\mu \mathrm{g} \mathrm{Ng}^{-1}\right.$ biomass $\left.\cdot \mathrm{day}^{-1}\right)$ & 1.04 & $\mathrm{~ns}$ & 0.02 & $\mathrm{~ns}$ & 0.73 & $\mathrm{~ns}$ \\
\hline Gross $\mathrm{N}$ uptake rate per field area $\left(\mathrm{mgNm}^{-2}\right.$ area $)$ & 1.05 & $\mathrm{~ns}$ & 2.02 & ns & 2.77 & ns \\
\hline \multicolumn{7}{|l|}{ (g) Plant $\mathrm{N}$ translocation to aboveground biomass } \\
\hline Specific $\mathrm{N}$ uptake rate $\left(\mathrm{mg} \mathrm{Ng}^{-1}\right.$ biomass $\cdot$ day $\left.^{-1}\right)$ & 1.12 & $\mathrm{~ns}$ & 0.011 & $\mathrm{~ns}$ & 11.98 & $* *$ \\
\hline $\mathrm{N}$ uptake rate per field area $\left(\mathrm{mg} \mathrm{Nm}^{-2} \mathrm{day}^{-1}\right)$ & 6.04 & $*$ & 1.25 & ns & 1.23 & ns \\
\hline \multicolumn{7}{|l|}{ (h) Plant root $\mathrm{N}$ uptake } \\
\hline Specific $\mathrm{N}$ uptake rate $\left(\mathrm{mgNg}^{-1}\right.$ biomass $\cdot$ day $\left.^{-1}\right)$ & 7.08 & * & 0.55 & ns & 23.43 & $* *$ \\
\hline $\mathrm{N}$ uptake rate per field area $\left(\mathrm{gNm}^{-2} \mathrm{day}^{-1}\right)$ & 4.84 & $\mathrm{~ns}$ & 0.07 & ns & 4.36 & $\mathrm{~ns}$ \\
\hline
\end{tabular}

\section{Results}

\subsection{Nitrogen dynamics after snowmelt}

\subsubsection{Plant biomass and growth}

At the beginning of the growing season, while aboveground biomass was the greatest in the unterraced grasslands (Supplement C1), plant RGR over one week was greater for terraced grasslands, indicating higher biomass production (Table 1). In contrast, there were no effects of current management (mown vs. unmown - Table 1). Root biomass was influenced by past land use and by the interaction of past and current land use since root biomass was greater in unterraced than in terraced grasslands, and greater in mown than in unmown terraces (Table 1, Supplement C1).

\subsubsection{Soil, microbial and plant $\mathrm{N}$ pools}

Soil N-NO ${ }_{3}^{-}$concentration differed according to land use and the differences were consistent whether expressed per soil mass or per soil area (Table 1, Supplement C1). Soil $\mathrm{N}-\mathrm{NO}_{3}^{-}$concentration was higher in terraced than in unterraced grasslands, and highest in the UT fields among the terraced grasslands (Table 1 , Supplement $\mathrm{C} 1$ ). Soil $\mathrm{N}-\mathrm{NH}_{4}^{+}$ concentration was only influenced by the interaction of past and current land use since UU fields had the highest soil $\mathrm{N}-\mathrm{NH}_{4}^{+}$concentrations, and MU fields the lowest (Table 1, Supplement C1). Past and current land use had an effect on 
soil N-NH$+4 / \mathrm{N}_{4} \mathrm{NO}_{3}^{-}$ratio, with a greater prevalence of $\mathrm{N}$ $\mathrm{NH}_{4}^{+}$in unterraced than in terraced grasslands; the ratio was smaller in unmown fields in both cases (Table 1, Supplement $\mathrm{C} 1$ ). Land use had no effect on microbial biomass $\mathrm{N}$ (MBN) but there were significant differences for the microbial $\mathrm{C}: \mathrm{N}$ ratio, with greater values in terraced than in unterraced grasslands (Table 1, Supplement C1).

Total aboveground $\mathrm{N}$ concentration per $\mathrm{g}$ of biomass did not vary with land use (Table 1). Because of higher plant biomass (per area), the aboveground $\mathrm{N}$ concentration varied between terraced and unterraced grassland (Table 1), and was higher in the UU fields than MT and UT fields (Supplement $\mathrm{C} 1$ ). Root $\mathrm{N}$ concentration did not change with land use on a field area basis (Table 1, Supplement C1). Conversely, root $\mathrm{N}$ concentration (per $\mathrm{g}$ of biomass) was greater in the terraces than in unterraced grasslands (Table 1, Supplement C1).

\subsubsection{Plant and microbial N uptake}

Specific root $\mathrm{N}$ uptake differed between land uses with a greater uptake in terraced than in unterraced grasslands (Supplement C2), and a differential effect of mowing dependent on past land use (Table 1). Specific root $\mathrm{N}$ uptake was greater in UT fields, intermediate in mown fields, and lower in UU fields (Supplement C2). Shoot N translocation (by area) was influenced by past land use and was higher in terraced than in the unterraced grasslands (Table 1, Supplement C2), and specific shoot $\mathrm{N}$ translocation (per $\mathrm{g}$ of aboveground biomass) differed for UU fields compared to the rest of the fields (Table 1, Supplement C2). Specific (per g of biomass) and gross (per area) microbial $\mathrm{N}$ uptakes did not differ across land uses (Table 1, Supplement C2).

Consumption rates of $\mathrm{N}^{-\mathrm{NO}_{3}^{-}}$both per $\mathrm{g}$ of soil or per area never differed among land use types, while the $\mathrm{N}$ $\mathrm{NH}_{4}^{+}$consumption was affected by past land use with higher rates in the terraced than unterraced grasslands (Table 1, Supplement C2).

\subsubsection{Seasonal contrasts on $\mathbf{N}$ dynamics}

The conceptual comparison of our results measured at the end of the snowmelt in May 2010 with data obtained at the peak of aboveground biomass in July 2005 offers an opportunity to unravel the temporal variability in the resource $(\mathrm{N})$ competition between plant and microbes in subalpine grasslands. However, one should keep in mind that other sources of variations such as inter-annual variability, biotic and abiotic interactions could participate to the observed differences besides seasonality. To limit this variability as much as possible, all selected grasslands were chosen in close vicinity within the same sub-watershed, with similar parent material, as well as comparable climatic conditions and $\mathrm{N}$ deposition rates (Clement et al., 2012).

\subsubsection{Variation in $\mathrm{N}$ pools}

Inorganic $\mathrm{N}$ availability in soil was extremely different between the peak biomass (July 2005, Robson et al., 2010) and the beginning of the growing season which begun at the end of snowmelt (May 2010, this study) suggesting some seasonal variations. We observed large changes in soil $\mathrm{N}_{-} \mathrm{NO}_{3}^{-}$ concentration, which was always greater at peak biomass than at the end of snowmelt (Table 2; Fig. 1a). Variation in soil $\mathrm{N}-\mathrm{NH}_{4}^{+}$concentration showed a different pattern with much smaller but significant differences between the two dates (Fig. 1b, Table 2). Past and current land uses also influenced soil $\mathrm{N}-\mathrm{NH}_{4}^{+}$concentration with lower values at the end of snowmelt in unterraced than in terraced grasslands $(F=21.57 ; p<0.001$, Table 2$)$; while no difference between the two sampling dates was observed in MT fields (Fig. 1b).

There were large differences in soil $\mathrm{N}^{-\mathrm{NO}_{3}^{-}}$consumption rate between the two sampling dates, with higher values in May for all fields ( $F=72.15 ; p<0.001$, Table 2$)$, even if a past land use effect was observed with no difference in UT fields (Fig. 1c). The consumption rates of $\mathrm{N}^{-\mathrm{NH}_{4}^{+}}$followed a different pattern depending on past land use $(F=12.69$; $p<0.05$, Table 2): they were larger in May 2010 only for MT fields; whereas they were higher in July 2005 for UM fields (Fig. 1d).

Other soil parameters (e.g. $\mathrm{pH}$, soil $\mathrm{C} / \mathrm{N}$ ratio and bulk density - data not shown) did not differ much across the two sampling dates. Only soil total $\mathrm{N}$ concentration was lower in May 2010 for all grasslands due to concomitant decreases of $\mathrm{N}^{-\mathrm{NO}_{3}^{-}}$and $\mathrm{N}-\mathrm{NH}_{4}^{+}$concentrations in soil and a greater consumption rate of these both $\mathrm{N}$ forms than in July 2005 (Fig. 1).

Microbial biomass $\mathrm{N}$ differed between the two sampling dates depending on past land use $(F=17.29 ; p<0.001$, Table 2). In the terraces, MBN were not different between the two sampling dates, whereas MBN strongly decreased in July for unterraced grasslands (Fig. 2a). This effect of sampling date was reflected in microbial $\mathrm{C}: \mathrm{N}$ ratio $(F=61.15$; $p<0.001$, Table 2) with no variation in the terraced grasslands, while $\mathrm{C}: \mathrm{N}$ ratio was twice as high in July $2005 \mathrm{com}-$ pared to May 2010 for both unterraced grasslands (Fig. 2b).

There was no difference in aboveground plant $\mathrm{N}$ per $\mathrm{g}$ of biomass between the two sampling dates (Table 2), whatever the land use. A slight effect of sampling date was observed in root $\mathrm{N}$ concentrations per $\mathrm{g}$ of biomass $(F=5.05 ; p<0.05)$, which were higher at the end of snowmelt only in terraced grasslands $(F=5.86 ; p<0.05)$. However, when expressed per area, a strong effect of sampling date was observed in aboveground and root $\mathrm{N}$ contents (Fig. 2c, d and Table 2).

\subsubsection{Variations in daily $\mathbf{N}$ uptake}

In all grasslands, shoot $\mathrm{N}$ translocation differed significantly between May 2010 and July 2005 ( $F=106.58 ; p<0.05$, 

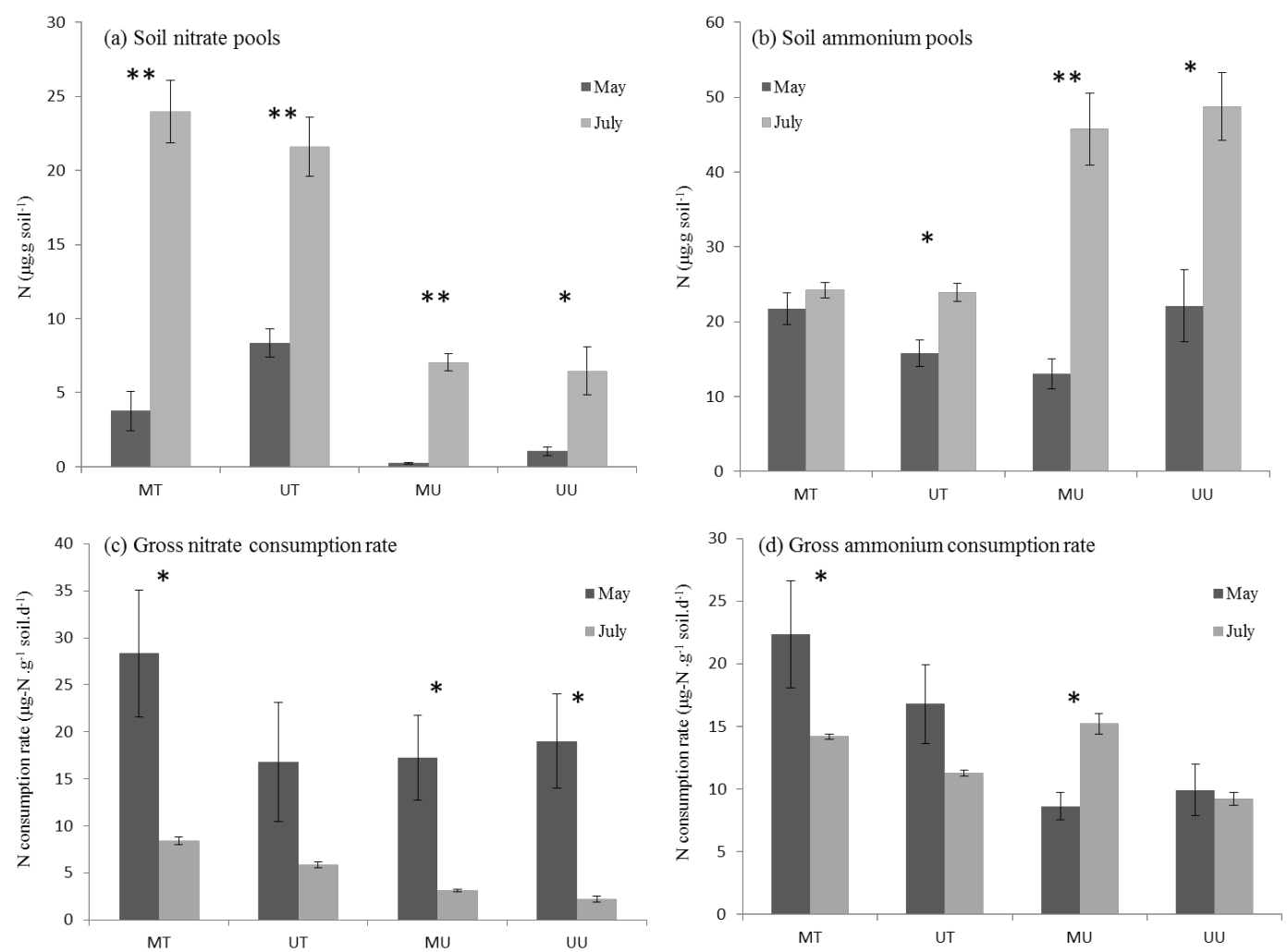

Fig. 1. Differences in soil inorganic nitrogen $(\mathrm{N})$ pools and fluxes between the end of snowmelt and the peak biomass in subalpine agricultural grasslands with distinct land uses. (a) Soil $\mathrm{N}_{-} \mathrm{NO}_{3}^{-}$and (b) $\mathrm{N}-\mathrm{NH}_{4}^{+}$available at the beginning of both experiments is calculated from N concentration for each $\mathrm{g}$ of soil. (c) Soil $\mathrm{N}-\mathrm{NO}_{3}^{-}$and (d) $\mathrm{N}-\mathrm{NH}_{4}^{+}$flux per day using the ${ }^{15} \mathrm{~N}$ pool dilutions for $48 \mathrm{~h}$ after inoculation from the isotope dilution equations of Kirkham and Bartholomew. Data from four $200 \mathrm{~cm}^{2}$ areas per fields were amalgamated to give mean values of three fields per land use \pm SE. Statistical analyses were done separately for each land use and stars represent significant differences $(*$ $<0.05 ; * *<0.01$ and $* * *<0.001)$.

Table 2). Specific shoot $\mathrm{N}$ translocation was $2-5$ times higher at the end of snowmelt in all grasslands even if rates differed between land uses (Fig. 3a). However, the 1.7 to 3.1fold increase in aboveground biomasses measured in July at peak biomass partially compensated for this higher $\mathrm{N}$ translocation per $\mathrm{g}$ of shoot in May (Table 2, Robson et al., 2010), resulting in similar shoot $\mathrm{N}$ translocation rate per area between May and July (Table 2). Specific root N uptake (per $\mathrm{g}$ of biomass) varied between the two sampling dates $(F=51.74 ; p<0.001$, Table 2$)$ and showed different effects depending on land uses $(F=12.72 ; p<0.01)$. This uptake was higher at peak biomass in all unterraced grasslands and MT fields, however no difference was apparent in UT fields (Fig. 3b). When expressed on a field area basis, root $\mathrm{N}$ uptake was greater in July 2005 only in unterraced grasslands $(F=17.65 ; p<0.001$; Table 2$)$. When shoot and root $\mathrm{N}$ uptakes were taken together, overall specific plant $\mathrm{N}$ uptake rate (per $\mathrm{g}$ of biomass) differed between the two sampling dates $(F=46.68 ; p<0.001$, Table 2$)$ and between the land uses. Specific plant N uptake was higher in May 2010 than in July 2005 in all terraced grasslands $(F=9.33 ; p<0.01)$ and in the mown unterraced grassland (Fig. 3c). A contrasting pattern was evident per area as there were some interactions between land use and plant $\mathrm{N}$ uptake (in $\mathrm{g} \mathrm{N} \mathrm{m}^{-2} \mathrm{~d}^{-1}$; $F=5.45 ; p<0.05$, Table 2), which was higher in July 2005 in all unterraced grasslands (Fig. 3d). In the terraced grasslands, plant $\mathrm{N}$ uptake per area did not differ in MT fields between the two sampling dates, but it was higher in UT fields at the end of snowmelt (Fig. 3d).

Specific microbial $\mathrm{N}$ uptake (per $\mathrm{g}$ of microbial biomass) showed no significant variations between the two sampling dates (Fig. 4a, Table 2), but these results showed that the existing differences in microbial $\mathrm{N}$ uptake between terraced and unterraced grasslands at peak biomass (Robson et al., 2010) disappeared by the end of snowmelt (Fig. 4a). Gross microbial $\mathrm{N}$ uptake (per area) revealed a different pattern between the two sampling dates $(F=120.32 ; p<0.001$, Table 2$)$ as it strongly decreased at the end of snowmelt in all grasslands with most contrasting differences in terraced rather than in unterraced grasslands (Fig. 4b).

Finally, we observed a switch in the importance of microbial and plant $\mathrm{N}$ uptake, since, on an area basis, plants were 
Table 2. Effect of sampling "time" (end of snowmelt 2010 vs. peak biomass 2005), and interaction with past (terraced vs. unterraced) and current (mown vs. unmown) land uses on $\mathrm{N}$ pools and fluxes of soil, plant and microbial communities. Values are results of ANOVAs $(F)$ and significance $\left({ }^{* * *} p<0.001,{ }^{* *} p<0.01,{ }^{*} p<0.05\right.$, ns: not significant).

\begin{tabular}{|c|c|c|c|c|c|c|c|c|c|c|c|c|c|c|}
\hline \multirow{3}{*}{ (a) Soil N pools } & \multicolumn{2}{|c|}{ Past } & \multicolumn{2}{|c|}{ Current } & \multicolumn{2}{|c|}{ Past $\times$ current } & \multicolumn{2}{|c|}{ Time } & \multicolumn{2}{|c|}{ Past $\times$ Time } & \multicolumn{2}{|c|}{ Current $\times$ time } & \multicolumn{2}{|c|}{ Past $\times$ current $\times$ time } \\
\hline & $F$ & $p$ & $F$ & $p$ & $F$ & $p$ & $F$ & $p$ & $F$ & $p$ & $F$ & $p$ & $F$ & $p$ \\
\hline & & & & & & & & & & & & & & \\
\hline $\mathrm{N}-\mathrm{NO}_{3}^{-}\left(\mathrm{ug} \mathrm{Ng}^{-1}\right.$ soil $)$ & 128.39 & $* * *$ & 2.90 & $\mathrm{~ns}$ & 0.33 & $\mathrm{~ns}$ & 157.6 & $* * *$ & 0.12 & $\mathrm{~ns}$ & 8.27 & $*$ & 0.77 & ns \\
\hline $\mathrm{N}-\mathrm{NH}_{4}^{+}\left(\mathrm{ugNg}^{-1}\right.$ soil $)$ & 10.95 & $* *$ & 0.52 & $\mathrm{~ns}$ & 7.48 & * & 62.2 & $* * *$ & 21.57 & $* * *$ & 0.16 & ns & 5.1 & * \\
\hline $\begin{array}{l}\text { Microbial biomass } \mathrm{N} \\
\left(\mathrm{gNm}^{-2} \text { area }\right)\end{array}$ & 16.08 & ** & 0.61 & ns & 0.52 & ns & 5.85 & $*$ & 17.29 & $* * *$ & 0.09 & ns & 3.64 & ns \\
\hline Microbial C/N & 0.64 & ns & 0.83 & ns & 1.4 & ns & 61.15 & $* * *$ & 17.51 & $* * *$ & 0.15 & ns & 0.01 & ns \\
\hline $\begin{array}{l}\text { Aboveground plant } \\
\left(\mathrm{mg} \mathrm{Ng}^{-1} \text { biomass }\right)\end{array}$ & 1.67 & ns & 2.75 & $\mathrm{~ns}$ & 0.59 & ns & 0.01 & $\mathrm{~ns}$ & 1.35 & ns & 0.01 & ns & 0.01 & ns \\
\hline Aboveground plant ( $\mathrm{g} \mathrm{Nm}^{-2}$ area) & 34.82 & ns & 1.42 & ns & 1.72 & ns & 24.87 & $* * *$ & 0.03 & ns & 3.21 & $\mathrm{~ns}$ & 0.01 & ns \\
\hline Root (mg Ng${ }^{-1}$ biomass) & 35.08 & $* * *$ & 0.19 & ns & 1.26 & ns & 5.05 & $*$ & 5.86 & $*$ & 0.21 & $\mathrm{~ns}$ & 1.77 & ns \\
\hline Root $\left(\mathrm{g} \mathrm{Nm}^{-2}\right.$ area $)$ & 4.83 & * & 4.75 & $*$ & 2.14 & ns & 14.18 & ** & 0.19 & ns & 1.66 & ns & 0.05 & ns \\
\hline (b) Soil inorganic $\mathrm{N}$ fluxes & & & & & & & & & & & & & & \\
\hline $\begin{array}{l}\text { Gross } \mathrm{N}-\mathrm{NO}_{3}^{-} \text {consumption rate } \\
\left(\mathrm{ug} \mathrm{Ng}^{-1} \text { soil } \cdot \text { day }^{-1} \text { ) }\right.\end{array}$ & 10.74 & ** & 3.67 & $\mathrm{~ns}$ & 1.31 & $\mathrm{~ns}$ & 72.15 & $* * *$ & 6.39 & * & 0.05 & $\mathrm{~ns}$ & 1.31 & ns \\
\hline $\begin{array}{l}\text { Gross } \mathrm{N}-\mathrm{NH}_{4}^{+} \text {consumption rate } \\
\left(\mathrm{ug} \mathrm{Ng}^{-1} \text { soil } \cdot \text { day }^{-1} \text { ) }\right.\end{array}$ & 18.93 & $* * *$ & 5.77 & $*$ & 0.08 & ns & 0.38 & ns & 12.69 & $* *$ & 2.1 & ns & 3.32 & ns \\
\hline $\begin{array}{l}\text { Microbial specific } \mathrm{N} \text { uptake rate } \\
\text { per }\left(\mathrm{ugNg}^{-1} \text { biomass } \cdot \mathrm{day}^{-1} \text { ) }\right.\end{array}$ & 28.01 & $* * *$ & 0.01 & $\mathrm{~ns}$ & 0.32 & $\mathrm{~ns}$ & 0.7 & $\mathrm{~ns}$ & 10.85 & $* *$ & 0.02 & $\mathrm{~ns}$ & 0.77 & ns \\
\hline $\begin{array}{l}\text { Microbial } \mathrm{N} \text { uptake rate per field } \\
\text { area }\left(\mathrm{mg} \mathrm{N}^{-2} \text { area }\right)\end{array}$ & 34.51 & $* * *$ & 0.91 & $\mathrm{~ns}$ & 1.29 & ns & 120.62 & $* * *$ & 17.96 & $* * *$ & 1.03 & ns & 1.08 & ns \\
\hline $\begin{array}{l}\text { Aboveground specific } \mathrm{N} \text { uptake rate } \\
\left(\mathrm{mg} \mathrm{Ng}^{-1} \text { biomass } \cdot \text { day }^{-1}\right)\end{array}$ & 0.27 & ns & 4.02 & $\mathrm{~ns}$ & 7.86 & * & 106.58 & $* * *$ & 6.01 & * & 1.16 & ns & 5.84 & * \\
\hline $\begin{array}{l}\text { Aboveground uptake rate per field } \\
\text { area }\left(\mathrm{mg} \mathrm{Nm}^{-2} \mathrm{day}^{-1}\right)\end{array}$ & 3.05 & $\mathrm{~ns}$ & 0.5 & $\mathrm{~ns}$ & 1.18 & ns & 0.64 & ns & 4.5 & ns & 1.03 & ns & 1.54 & ns \\
\hline $\begin{array}{l}\text { Root specific } \mathrm{N} \text { uptake } \\
\text { rate }\left(\mathrm{mg} \mathrm{Ng}^{-1} \text { biomass } \cdot \text { day }^{-1}\right)\end{array}$ & 0.05 & $\mathrm{~ns}$ & 3.03 & $\mathrm{~ns}$ & 3.31 & $\mathrm{~ns}$ & 51.74 & $* * *$ & 10.16 & $* *$ & 6.61 & $*$ & 12.72 & $* *$ \\
\hline $\begin{array}{l}\text { Root } \mathrm{N} \text { uptake rate per field } \\
\text { area }\left(\mathrm{g} \mathrm{Nm}^{-2} \mathrm{day}^{-1}\right)\end{array}$ & 1.48 & $\mathrm{~ns}$ & 2.84 & $\mathrm{~ns}$ & 0.91 & $\mathrm{~ns}$ & 39.46 & $* * *$ & 17.65 & $* * *$ & 2.29 & $\mathrm{~ns}$ & 7.71 & * \\
\hline $\begin{array}{l}\text { Total plant specific } \mathrm{N} \text { uptake rate } \\
\left(\mathrm{mgNg}^{-1} \text { biomass } \cdot \text { day }^{-1}\right)\end{array}$ & 0.19 & $\mathrm{~ns}$ & 5.78 & $*$ & 8.61 & $* *$ & 46.68 & $* * *$ & 9.33 & $* *$ & 2.23 & ns & 12.5 & $* *$ \\
\hline $\begin{array}{l}\text { Total plant } \mathrm{N} \text { uptake rate per field } \\
\text { area }\left(\mathrm{gNm}^{-2} \mathrm{day}^{-1}\right)\end{array}$ & 0.26 & $\mathrm{~ns}$ & 0.57 & $\mathrm{~ns}$ & 4.55 & $*$ & 3.64 & $\mathrm{~ns}$ & 20.16 & $* * *$ & 9.12 & $* *$ & 5.45 & $*$ \\
\hline
\end{tabular}

generally the strongest sink for inorganic $\mathrm{N}$ at the end of the snowmelt (Fig. 4c) whereas microbes dominated $\mathrm{N}$ uptake at peak biomass (Fig. 4d). However, these patterns were also influenced by land uses, and in different ways at the two sampling dates. At peak biomass (i.e., July 2005; Fig. 4d), microbes dominated daily $\mathrm{N}$ uptake in terraced grasslands but not in unterraced grasslands $(F=45.16 ; p<0.001)$. At the end of snowmelt (i.e., May 2010; Fig. 4c), no clear pattern was observed: plants took up more inorganic $\mathrm{N}$ than microbes in the UT and MU fields, whereas no difference was observed in the two others grasslands $(F=7.43 ; p<0.05)$.

\section{Discussion}

Our results revealed that inorganic $\mathrm{N}$ uptake patterns for plant and microbial communities in subalpine grasslands differed markedly between the end of snowmelt and those previously documented at peak vegetation (Robson et al., 2010). No difference in specific microbial $\mathrm{N}$ uptake (per $\mathrm{g}$ of microbial biomass) was apparent between the two sampling dates (Fig. 4a), though gross microbial uptake (per area) was much lower in May 2010 than in July 2005 in all grasslands (Fig. 4b). The contrasting plant communities did not benefit in the same way from this microbial quiescence. In line with our expectations, the most intensively managed plant communities (terraced grasslands and mown unterraced grasslands) took up more inorganic $\mathrm{N}$ at the end of snowmelt than at peak biomass, whereas plant communities in unmown unterraced grasslands maintained similar inorganic $\mathrm{N}$ uptake rates between the two sampling dates (Fig. 3c).

\subsection{N pools variations across season and land uses}

Nutrient availability and the ability to take up inorganic $\mathrm{N}$ efficiently are critical plant features in arctic and alpine ecosystems characterized by slow $\mathrm{N}$ mineralization rates (Bardgett et al., 2007). After a long period of snow cover and low temperatures, rising daily temperatures allow snowmelt that increases soil moisture and consequently nutrient availability (Brooks et al., 1998; Clément et al., 2012; Saccone et al., 2013). In our study, soil $\mathrm{N}-\mathrm{NO}_{3}^{-}$and $\mathrm{N}-\mathrm{NH}_{4}^{+}$pools at the end of snowmelt were much lower than at peak biomass, and this difference in soil DIN was much larger in unterraced than in terraced grasslands (Fig. 1). Although some studies in cold ecosystems have reported a similar reduction in inorganic $\mathrm{N}$ pools during or at the end of snowmelt (Brooks et al., 1996; Edwards et al., 2006), these results contradict 

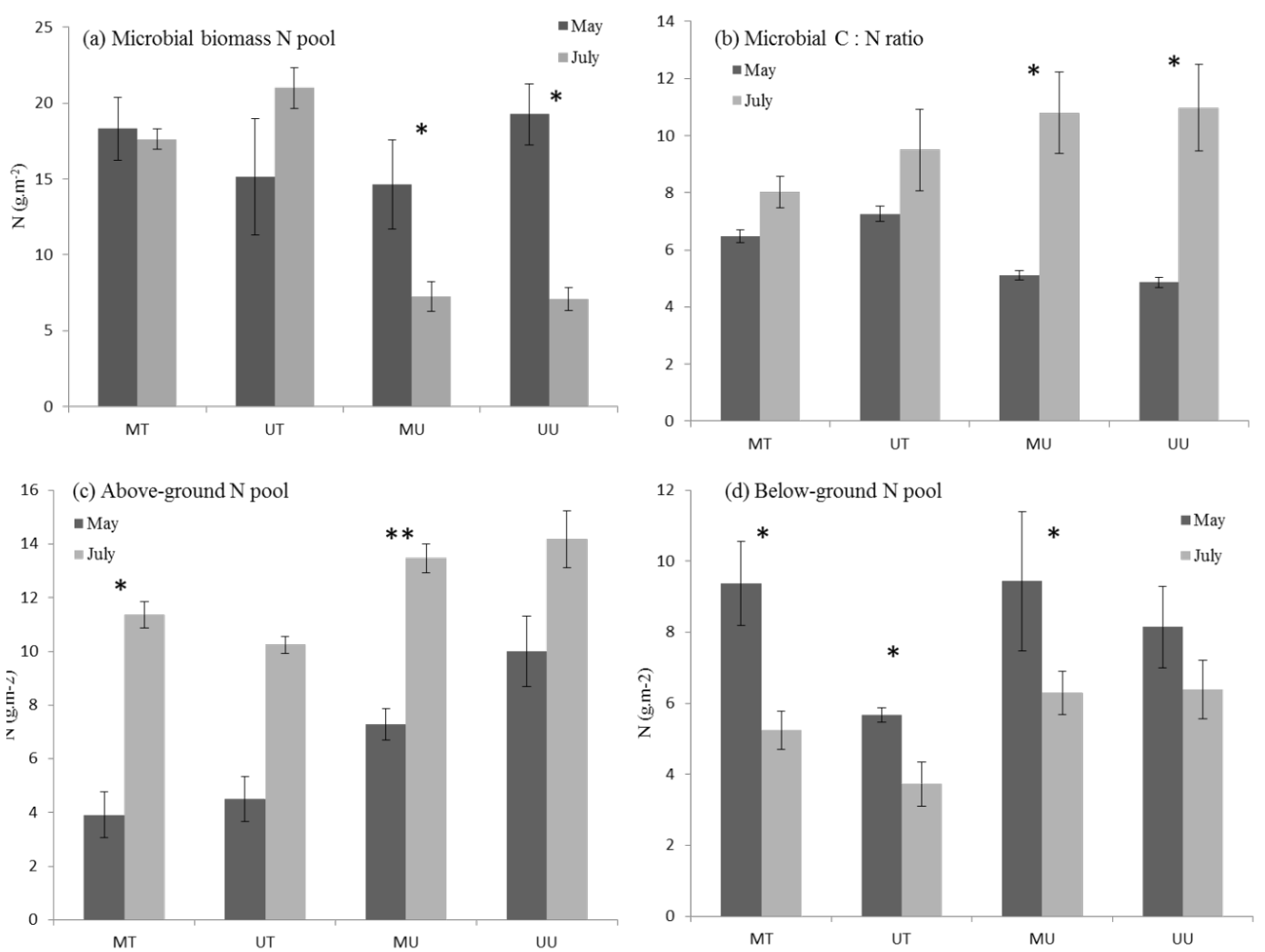

Fig. 2. Differences in soil microbial and plant nitrogen $(\mathrm{N})$ pools between the end of snowmelt and the peak biomass in each subalpine agricultural grasslands with distinct land uses. (a) Microbial $\mathrm{N}$ pool and (b) microbial $\mathrm{C}: \mathrm{N}$ ratio at the beginning of both experiments is calculated from the microbial $\mathrm{N}$ concentration $x$ biomass per $\mathrm{m}^{-2}$. (c) Aboveground $\mathrm{N}$ and (d) root $\mathrm{N}$ pools at the beginning of the both experiments are calculated from leaf or root $\mathrm{N}$ concentration $x$ biomass per $\mathrm{m}^{-2}$. Data from four $200 \mathrm{~cm}^{2}$ areas per fields were amalgamated to give mean values of three fields per land use \pm SE. Statistical analyses were done separately for each land use and stars represent significant differences $(*<0.05 ; * *<0.01$ and $* * *<0.001)$.

other studies showing that spring is often characterized by the release of soil inorganic N (Bardgett et al., 2002, 2005), or by the absence of seasonal cycles in $\mathrm{N}$ contents (Bardgett et al., 2007; Werdin-Pfisterer et al., 2009). Our results support the hypotheses that dissolved inorganic (DIN) or organic nitrogen (DON) released by microbial biomass was, either, immediately re-immobilized by microbial communities, as consistent with a microbial turnover greater than the mineralization rate (Brooks et al., 1996; Fisk et al., 1998; Schmidt et al., 2004); or that these different $\mathrm{N}$ forms could have been taken up by plants (Fig. 5), denitrified or leached during snowmelt (Schmidt et al., 2007). The evidence for this is two-fold. Firstly, we recovered $60-78 \%$ of the total ${ }^{15} \mathrm{~N}$ one week after the labelling (similar recovery rate in 2005). A substantial loss of $\mathrm{NO}_{3}^{-}$by leaching could reduce the DIN pool at the end of snowmelt compared to peak biomass, or inorganic $\mathrm{N}$ could be incorporated into soil organic matter via abiotic processes involving the fixation of $\mathrm{NH}_{4}^{+}$(Johnson et al., 2000). Secondly, the high mean $\mathrm{N}^{-\mathrm{NO}_{3}^{-}}$consumption rate in all grasslands, and of $\mathrm{N}-\mathrm{NH}_{4}^{+}$in mown grasslands, confirmed that DIN had been taken up (Fig. 1c, d). Because gross microbial $\mathrm{N}$ uptake was 4-9 times lower at the end of snowmelt than at peak biomass (Fig. 4b), absorption and retention by plant communities of the DIN released by microbial communities is a more likely explanation (Brooks et al., 1998; Jaeger et al., 1999; Bilbrough et al., 2000; Miller et al., 2009).

\subsection{Variations in plant $\mathrm{N}$ uptake between snowmelt and peak biomass}

In unmown grasslands, aboveground $\mathrm{N}$ concentrations did not vary between snowmelt and peak biomass but were higher in mown grasslands at peak biomass (Fig. 2c) whereas root $\mathrm{N}$ concentrations were usually higher at the end of snowmelt than at peak biomass (Fig. 2d; Jaeger and Manson, 1992; Bardgett et al., 2002). Greater root N concentrations in May 2010 may be related either to stored $\mathrm{N}$ allowing initial growth and re-allocation to shoots, or to $\mathrm{N}$ taken up by roots becoming active before snowmelt (Henry and Jefferies, 2002; Miller et al., 2009). This latter possibility was consistent with our results (Fig. 3b) showing high $\mathrm{N}$ uptake by roots together with fast and active $\mathrm{N}$ translocation 

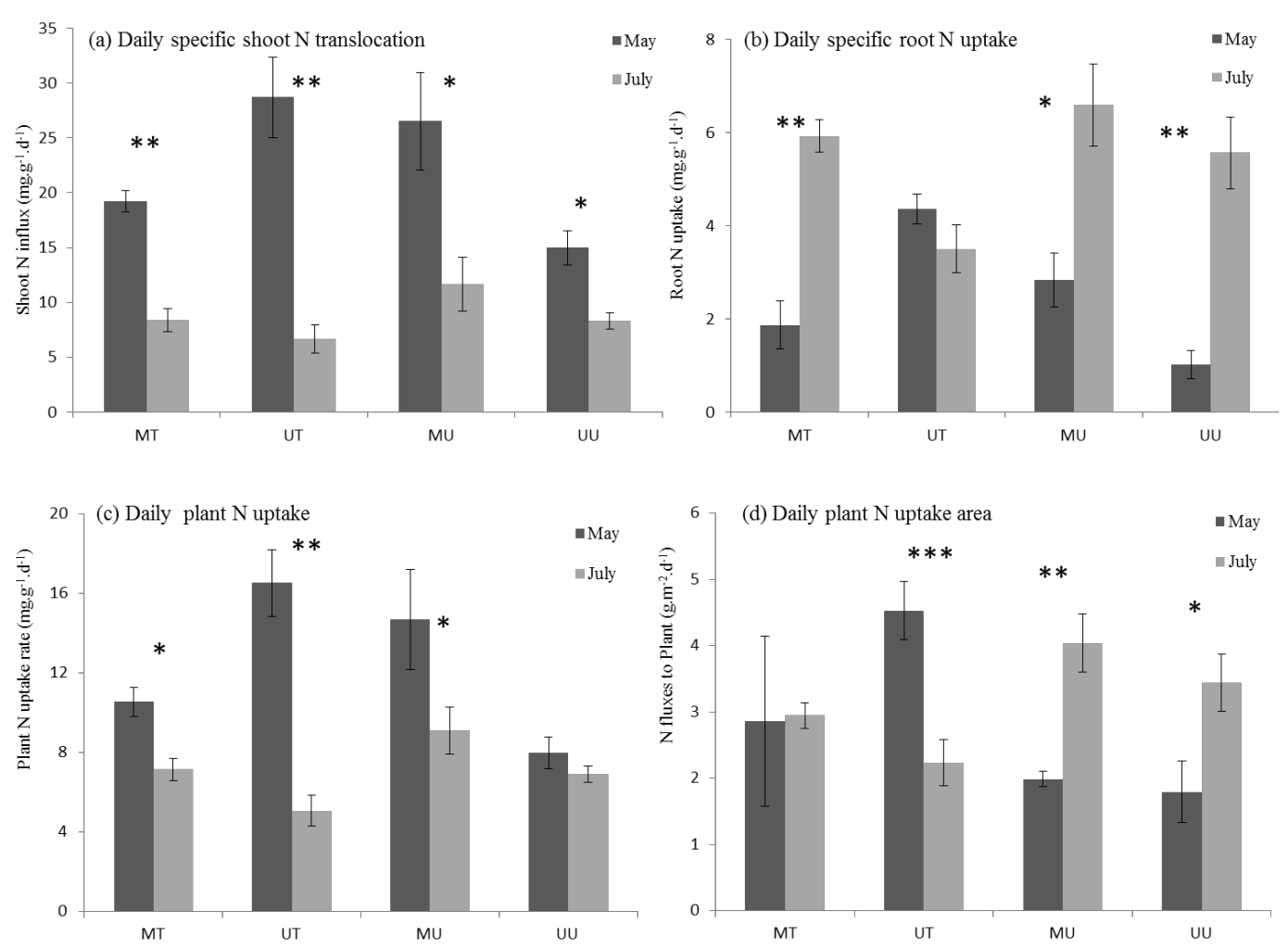

Fig. 3. Differences in plant nitrogen $(\mathrm{N})$ fluxes between the end of snowmelt and the peak biomass in subalpine agricultural grasslands with distinct land uses. The fluxes of nitrogen (N) into (a) aboveground plant tissue, (b) belowground plant tissue are expressed on a per-gbiomass basis. The flux of $\mathrm{N}$ into the entire plant per day (c) is expressed on a per-g-biomass basis and (d) on a per-area basis. Uptake of $\mathrm{N}$ is calculated from the ${ }^{15} \mathrm{~N}$ concentration and the soil ${ }^{14} \mathrm{~N}:{ }^{15} \mathrm{~N}$ ratio. Data from four $200 \mathrm{~cm}^{2}$ areas per fields were amalgamated to give mean values of three fields per land use \pm SE. Statistical analyses were done separately for each land use and stars represent significant differences $(*<0.05 ; * *<0.01$ and $* * *<0.001)$.

towards the aboveground parts at the onset of growth after snowmelt. In fact, we observed active total (root + shoot) inorganic $\mathrm{N}$ acquisition by plant communities in all grasslands at the end of snowmelt (Fig. 3c). Even if root $\mathrm{N}$ uptake was weaker than at peak biomass (Fig. 3b), shoot $\mathrm{N}$ translocation was at least double that of summer (Fig. 3a). In other words, after snowmelt, roots were taking up inorganic ${ }^{15} \mathrm{~N}$, but this $\mathrm{N}$ did not accumulate in the root system as it was immediately transported into the aerial parts of the plants (Fig. 5). These trends for subalpine grasslands are consistent with numerous studies in other cold ecosystems (Jaeger et al., 1999, Bilbrough et al., 2000; Bardgett et al., 2002; Miller et al., 2009). Plant $\mathrm{N}$ uptake was also impacted by past land use (terraced vs. unterraced), since plant communities in different grasslands differed in their uptake of available inorganic N. We hypothesize that these differences were linked to differences in RGR between contrasting plant communities present in terraced and unterraced grasslands (Supplement C1), since specific plant N uptake (per g biomass) in May 2010 increased with plants RGR (Fig. 3c, Supplement C1). These results suggest that higher DIN uptake at the beginning of the season could allow plant species to ensure biomass production even within a short growing season. As such, our results contrast with other studies in alpine or arctic meadows which report that $\mathrm{N}$ taken up during spring was not translocated to shoots, but remained in the roots (Edwards and Jefferies, 2010; Jaeger and Monson, 1992). Another explanation could be linked to the ability of species to express different uptake patterns depending on $\mathrm{N}$ forms availability (Stahl et al., 2011). This is illustrated by soil $\mathrm{N}^{-\mathrm{NO}_{3}^{-}}$decreasing more in unterraced than in terraced grasslands (Fig. 1a), and modifying the proportion of the different DIN forms available in soil through an increase of soil N-NH$+\mathrm{N}_{4}^{+} / \mathrm{N}^{-\mathrm{NO}_{3}^{-}}$ratio (Supplement $\mathrm{C} 1$, Robson et al., 2010). Therefore, in these subalpine grasslands, clear differences characterized vegetation between the two sampling dates. Plant communities switched from reduced plant biomass, high DIN uptake and high $\mathrm{N}$ concentration in plant tissues at the end of snowmelt to high plant biomass with low DIN uptake and low $\mathrm{N}$ concentration in plant tissues and at peak biomass when plant growth was finished. 

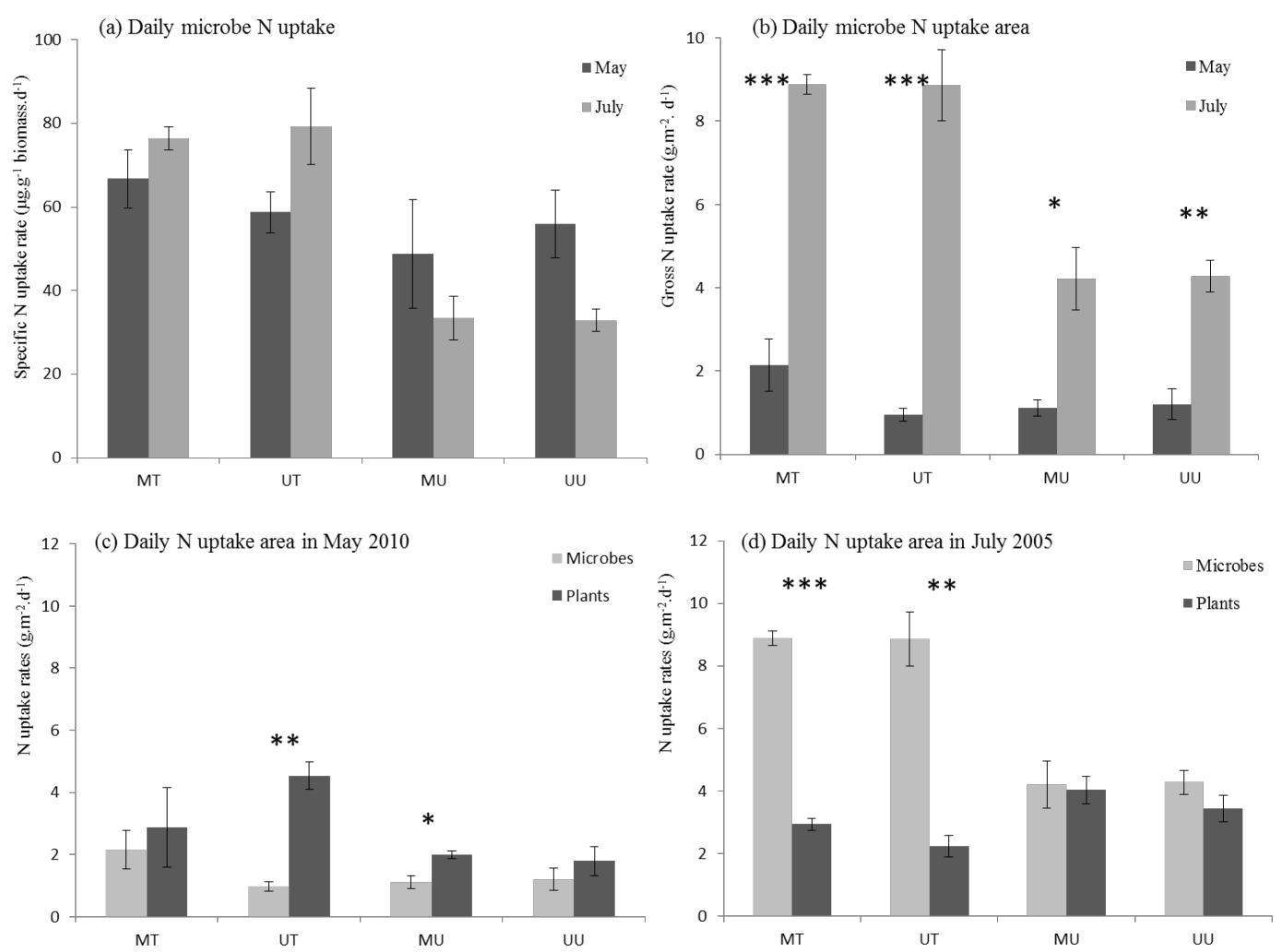

Fig. 4. Differences in soil microbial and plant nitrogen $(\mathrm{N})$ fluxes between the end of snowmelt and the peak biomass in subalpine agricultural grasslands with distinct land uses. The flux of nitrogen $(\mathrm{N})$ into microbial biomass per day is expressed (a) on per-g-biomass basis and (b) on per-area basis. The fluxes of nitrogen (N) into plants (black bars) and microbes (grey bars) are given for (c) May 2010 and (d) July 2005. Uptake of $\mathrm{N}$ is calculated from the ${ }^{15} \mathrm{~N}$ concentration and the soil ${ }^{14} \mathrm{~N}:{ }^{15} \mathrm{~N}$ ratio. Data from four $200 \mathrm{~cm}^{2}$ areas per fields were amalgamated to give mean values of three fields per land use \pm SE. Statistical analyses were done separately for each land use and stars represent significant differences $(*<0.05 ; * *<0.01$ and $* * *<0.001)$.

\subsection{Microbial N uptake during the growing season}

The higher $\mathrm{N}$ uptake rates by overall (shoot + root) plant communities contrasted with microbial communities (Fig. 4). In fact, we report a lower gross microbial $\mathrm{N}$ uptake rate in all grasslands at the end of the snowmelt in comparison to that at peak biomass (Fig. 4b). Yet, MBN remained similar in terraced grasslands for both sampling dates while, conversely, in unterraced grasslands MBN was smaller at peak biomass than at snowmelt (Fig. 2a). A similar contrast was evident for the microbial $\mathrm{C} / \mathrm{N}$ ratio which was greater at peak biomass than at snowmelt only in unterraced fields (Fig. 2b).

Such steady microbial N pools across seasons in terraced grasslands, concurs with one study in a mountain grassland (Bardgett et al., 2007), but contrasts with several other studies in cold ecosystems which described a decrease in microbial $\mathrm{N}$ contents and a release of available $\mathrm{N}$ at the end of snowmelt, reflecting a microbial crash in response to repeated freeze-thaw cycles (Brooks et al., 1998; Jaeger et al., 1999; Lipson et al., 1999; Bardgett et al., 2002; Edwards et al., 2006). This lack of seasonal variability could suggest that these microbial communities are adapted and resistant to freeze-thaw events (Lipson and Monson, 1998), which would limit the microbial crash to a microbial quiescence (Schimel et al., 2007). Consequently, a steady-state level of $\mathrm{N}$ in microbial biomass could result from $\mathrm{N}$ immobilization during winter or, alternatively, an immediate re-immobilization of released $\mathrm{N}$ could occur if microbial turnover was greater than the mineralization rate (Fisk et al., 1998). These hypotheses would explain the consistent MBN between snowmelt and peak biomass in spite of a lower gross microbial uptake of ${ }^{15} \mathrm{~N}$ tracer in the terraced grasslands of our study. Conversely, to our knowledge, this is the first report of an increase in the microbial $\mathrm{N}$ pool at the end of snowmelt, as we observed in unterraced grasslands. Here, these differences between the two sampling dates suggest a change in microbial communities, a hypothesis supported by the coupling of an increasing $\mathrm{MBN}$ with a decrease of microbial $\mathrm{C}: \mathrm{N}$ ratio at the end of the snowmelt (Fig. 2a, b). A possible explanation for this is the development of microbial communities with proteolytic abilities, allowing them to grow on protein released after the winter microbial community crash (Lipson 


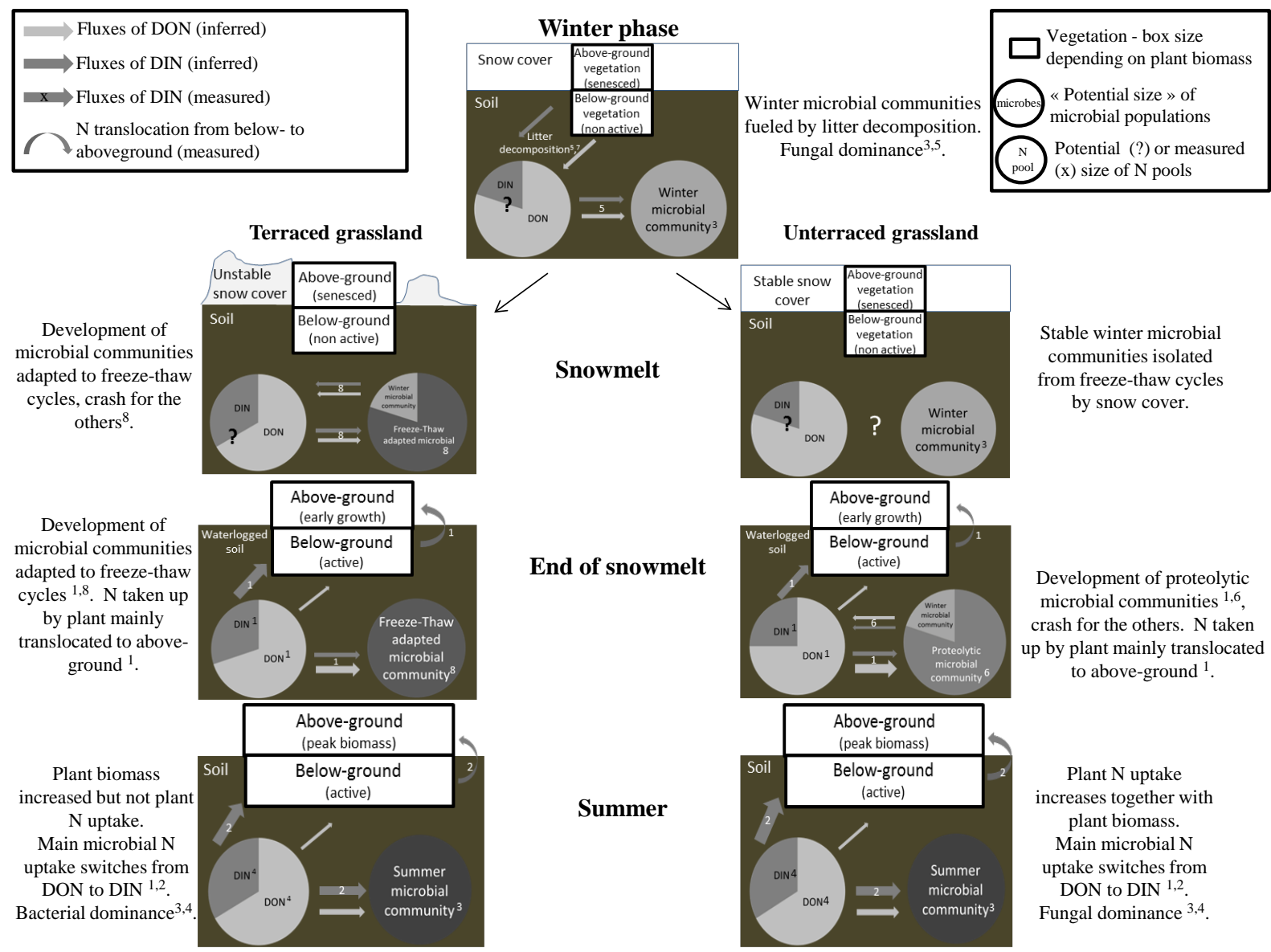

Fig. 5. Schematic diagram showing trends in nitrogen $(\mathrm{N})$ pools and fluxes in the two grasslands, terraced and unterraced, for the different phases of the growing season. Diagram based on the results of this paper and on the literature for soil microbial community changes. The vegetation box size is proportional to plant biomass and arrow size is proportional to the $\mathrm{N}$ fluxes inferred or measured. Legend: DIN: dissolved inorganic nitrogen; DON: dissolved organic nitrogen. Data sources: 1: this paper; 2: Robson et al. (2010); 3: Bardgett et al. (2005); 4: Grigulis et al. (2013); 5: Schmidt and Lipson (2004); 6: Lipson et al. (1999); 7: Saccone et al. (2013); 8: Lipson and Monson (1998).

et al., 1999). According to the literature, these proteolytic communities are characterized by a low $\mathrm{C}: \mathrm{N}$ ratio and fueled by proteins, which may explain the weaker inorganic $\mathrm{N}$ microbial uptake at the end of snowmelt in unterraced grasslands (Figs. 4b and 5). The differences in soil $\mathrm{pH}$ among land uses also support this suggestion since, in contrast to the terraces, unterraced grasslands had an acidic soil (Robson et al., 2010), which has been shown to stimulate extracellular protease activity (Henry and Jefferies, 2002).

The consistent level or the increase of MBN in terraced and unterraced grasslands, respectively, coupled with the fact that microbial communities were less able to take up inorganic $\mathrm{N}$ at the end of snowmelt than at peak biomass, suggested that another $\mathrm{N}$ source was available for soil microorganisms. We hypothesize that microbes mainly incorporated DON coming from the turn-over of those winter microbial communities impacted by freeze-thaw cycles (Bardgett et al., 2007; Schmidt et al., 2007). This concurs with data obtained at the end of the snowmelt in unterraced grasslands where low DIN pools (Fig. 1) associated with reduced rates of gross microbial inorganic $\mathrm{N}$ uptake (Fig. 4b) could not explain the increase of MBN (Fig. 2a) and concomitant decrease of microbial $\mathrm{C}: \mathrm{N}$ ratio (Fig. 2b). Consequently, in unterraced grasslands, DON could represent the main $\mathrm{N}$ source for microbes (Harrison et al., 2007), and maybe for plants, and it could explain the reduced $\mathrm{N}-\mathrm{NH}_{4}^{+}$concentrations and consumption rates measured at the end of snowmelt. Finally, a decrease of net $\mathrm{N}$ mineralization rates in unterraced grasslands has already been related to a decline in ammonification rates due to low soil temperatures (Robson et al., 2007), confirming that $\mathrm{N}-\mathrm{NH}_{4}^{+}$production can be limited at this time of the year.

Our results highlighted large differences on inorganic $\mathrm{N}$ dynamics at two critical times of the growing season. Higher consumption rates of DIN, notably $\mathrm{NO}_{3}^{-}$, were measured at the end of snowmelt compared to peak biomass, and these were explained by differing plant and microbial $\mathrm{N}$ uptakes. In all grasslands, at the end of snowmelt soil DIN consumption 
was high and dominated by plant uptake; whereas at peak biomass soil DIN consumption was lower and dominated by microbial immobilization (Robson et al., 2010). In addition to this $\mathrm{N}$ partitioning on these two contrasted sampling dates, the responses of the plant and microbial communities differed greatly according to the past land use at the site. While no seasonal variations in MBN were observed on terraces, a large increase occurred in unterraced grasslands and was accompanied by a decrease in the microbial $\mathrm{C}: \mathrm{N}$ ratio. Based on these results and on the literature, we suggest that proteolytic microbial communities developed in unterraced grasslands where they could assimilate DON originating from the crash of winter microbial communities rather than inorganic $\mathrm{N}$ (Lipson et al., 1999). Benefiting from changes in microbial DIN uptake, plant communities on terraced grasslands could maximize their growing capacities as they were able to efficiently assimilate DIN released by the turn-over of winter microbial communities. On the other hand, in unterraced grasslands, plant communities showed weaker specific $\mathrm{N}$ uptake capacities even though they maintained slow and steady growth rates. Thus, in the absence of any large sinks for inorganic $\mathrm{N}$ in microbial communities at the end of snowmelt, plant communities are therefore likely to represent a large sink for inorganic $\mathrm{N}$ at the beginning of the growing season in subalpine grasslands. Further investigations into microbial community composition and their $\mathrm{N}$ uptake dynamics through phospholipid fatty acid analysis and isotopic labeling of organic nitrogen, respectively, are required to better understand the decrease in microbial DIN uptake. These additional experiments would test our hypothesis that changes in the soil microbial community structure of these subalpine grasslands occur in the response to land use and seasonal changes.

\section{Supplementary material related to this article is available online at http://www.biogeosciences.net/10/ 7631/2013/bg-10-7631-2013-supplement.pdf.}

Acknowledgements. This study was conducted as part of ERA-Net BiodivERsA project VITAL, ANR-08-BDVA-008. The Lautaret site is part of the long-term research site Zone Atelier Alpes, a member of the ILTER-Europe and LTSER networks. We acknowledge the Joseph Fourier Alpine research station (CNRS UMS 3370) for infrastructure support, and Hanna Secher-Frommell for help with field and lab measurements at Lautaret.

Edited by: Z. Jia

\section{References}

Baptist, F., Zinger, L., Clement, J. C., Gallet, C., Guillemin, R., Martins, J. M. F., Sage, L., Shahnavaz, B., Choler, P., and Geremia, R.: Tannin impacts on microbial diversity and the functioning of alpine soils: a multidisciplinary approach, Environ. Microbiol., 10, 799-809, 2008.

Baptist, F., H. Secher-Fromell, F. Viard-Cretat, I. Aranjuelo, J. C. Clement, A. Creme, M. Desclos, P. Laine, S. Nogues, and S. Lavorel: Carbohydrate and nitrogen stores in Festuca paniculata under mowing explain dominance in subalpine grasslands, Plant Biol., 15, 395-404, 2013.

Bardgett, R. D., Streeter, T. C., Cole, L., and Hartley, I. R.: Linkages between soil biota, nitrogen availability, and plant nitrogen uptake in a mountain ecosystem in the Scottish Highlands, Appl. Soil Ecol., 19, 121-134, 2002.

Bardgett, R. D., Bowman, W. D., Kaufmann, R., and Schmidt, S. K.: A temporal approach to linking aboveground and belowground ecology, Trends Ecol. Evolut., 20, 634-641, 2005.

Bardgett, R. D., van der Wal, R., Jonsdottir, I. S., Quirk, H., and Dutton, S.: Temporal variability in plant and soil nitrogen pools in a high-Arctic ecosystem, Soil Biol. Biochem., 39, 2129-2137, 2007.

Bilbrough, C. J., Welker, J. M., and Bowman, W. D.: Early spring nitrogen uptake by snow-covered plants: A comparison of arctic and alpine plant function under the snowpack, Arc. Ant. Alpine Res., 32, 404-411, 2000.

Bowman, W. D., Bahnj, L., and Damm, M.: Alpine landscape variation in foliar nitrogen and phosphorus concentrations and the relation to soil nitrogen and phosphorus availability, Arc. Ant. Alpine Res., 35, 144-149, 2003.

Brookes, P. C., Kragt, J. F., Powlson, D.S., and Jenkinson, D. S.: Chloroform Fumigation And The Release Of Soil-Nitrogen The Effects Of Fumigation Time And Temperature, Soil Biol. Biochem., 17, 831-835, 1985.

Brooks, P. D., Williams, M. W., and Schmidt, S. K.: Microbial activity under alpine snowpacks, Niwot Ridge, Colorado, Biogeochemistry, 32, 93-113, 1996.

Brooks, P. D., Williams, M. W., and Schmidt, S. K.: Inorganic nitrogen and microbial biomass dynamics before and during spring snowmelt, Biogeochemistry, 43, 1-15, 1998.

Clement, J. C., Robson, T. M., Guillemin, R., Saccone, P., Lochet, J., Aubert, S., and Lavorel, S.: The effects of snow-N deposition and snowmelt dynamics on soil-N cycling in marginal terraced grasslands in the French Alps, Biogeochemistry, 108, 297-315, 2012.

Edwards, K. A., McCulloch, J., Kershaw, G. P., and Jefferies, R L.: Soil microbial and nutrient dynamics in a wet Arctic sedge meadow in late winter and early spring, Soil Biol. Biochem., 38 , 2843-2851, 2006.

Edwards, K. A. and Jefferies, R. L.: Nitrogen uptake by Carex aquatilis during the winter-spring transition in a low Arctic wet meadow, J. Ecol., 98, 737-744, 2010.

Finzi, A. C., Austin, A. T., Cleland, E. E., Frey, S. D., Houlton, B. Z., and Wallenstein, M. D.: Responses and feedbacks of coupled biogeochemical cycles to climate change: examples from terrestrial ecosystems, Front. Ecol. Environ., 9, 61-67, 2011.

Fisk, M. C., Schmidt, S. K., and Seastedt, T. R.: Topographic patterns of above- and belowground production and nitrogen cycling in Alpine tundra, Ecology, 79, 2253-2266, 1998. 
Girel, J., Quetier, F., Bignon, A., and Aubert, S.: Histoire de l'Agriculture en Oisans, Station Alpine Joseph Fourier, Grenoble, France, 2010.

Grigulis, K., Lavorel S., Krainer U., Legay N., Baxendale C., Dumont M., Kastl E., Arnoldi C., Bardgett R. D., Poly F., Pommier T., Schloter M., Tappeiner U., Bahn M., and Clément J.-C.: Relative contributions of plant traits and soil microbial properties to mountain grassland ecosystem services, J. Ecol., 101, 47-57, 2013.

Harrison, K. A., Bol, R., and Bardgett, R. D. Preferences for different nitrogen forms by coexisting plant species and soil microbes, Ecology, 88, 989-999, 2007.

Harrison, K. A., Bol, R., and Bardgett, R. D.: Do plant species with different growth strategies vary in their ability to compete with soil microbes for chemical forms of nitrogen?, Soil Biol. Biochem., 40, 228-237, 2008.

Henry, H. A. L. and Jefferies, R. L.: Free amino acid, ammonium and nitrate concentrations in soil solutions of a grazed coastal marsh in relation to plant growth, Plant Cell Environ., 25, 665$675,2002$.

Jaeger, C. H. and Monson, R. K.: Adaptive significance of nitrogen storage in Bistorta-Bistortoides, an alpine herb, Oecologia, 92, 578-585, 1992.

Jaeger, C. H., Monson, R. K., Fisk, M. C., and Schmidt, S. K.: Seasonal partitioning of nitrogen by plants and soil microorganisms in an alpine ecosystem, Ecology, 80, 1883-1891, 1999.

Jefferies, R. L., Walker N. A., Edwards K. A., and Dainty, J.: Is the decline of soil microbial biomass in late winter coupled to changes in the physical state of cold soils?, Soil Biol. Biochem., 42, 129-135, 2010.

Johnson, D. W., Cheng, W., and Burke, I. C.: Biotic and abiotic nitrogen retention in a variety of forest soils, Soil Sci. Soc. Am. J., 64, 1503-1514, 2000.

Jones, D. L. and Willett, V. B.: Experimental evaluation of methods to quantify dissolved organic nitrogen (DON) and dissolved organic carbon (DOC) in soil, Soil Biol. Biochem., 38, 991-999, 2006.

Kaye, J. P. and Hart, S. C.: Competition for nitrogen between plants and soil microorganisms, Trends Ecol. Evolut., 12, 139-143, 1997.

Larsen, K. S., Michelsen A., Jonasson S., Beier C., and Grogan P.: Nitrogen Uptake During Fall, Winter and Spring Differs Among Plant Functional Groups in a Subarctic Heath Ecosystem, Ecosystems, 15, 927-939. 2012.

Lipson, D. A. and Monson, R. K.: Plant-microbe competition for soil amino acids in the alpine tundra: effects of freeze-thaw and dry-rewet events, Oecologia, 113, 406-414, 1998.

Lipson, D. A. and Nasholm, T.: The unexpected versatility of plants: organic nitrogen use and availability in terrestrial ecosystems, Oecologia, 128, 305-316, 2001.

Lipson, D. A., Schmidt, S. K., and Monson, R. K.: Links between microbial population dynamics and nitrogen availability in an alpine ecosystem, Ecology, 80, 1623-1631, 1999.

Malik, T. and Smith, H.: A resource-based model of microbial quiescence, J. Mathemat. Biol., 53, 231-252, 2006.

Mancinelli, R. L. Population-Dynamics Of Alpine Tundra Soil Bacteria, Niwot Ridge, Colorado Front Range, Usa, Arc. Alpine Res., 16, 185-192, 1984.
Miller, A. E., Schimel, J. P., Sickman, J. O., Skeen, K., Meixner, T., and Melack, J. M.: Seasonal variation in nitrogen uptake and turnover in two high-elevation soils: mineralization responses are site-dependent, Biogeochemistry, 93, 253-270, 2009.

Mullen, R. B., Schmidt, S. K., and Jaeger, C. H.: Nitrogen uptake during snowmelt by the snow buttercup, Ranunculus adoneus, Arc. Alpine Res., 30, 121-125, 1998.

Quetier, F., Lavorel, S., Thuiller, W., and Davies, I.: Plant-traitbased modeling assessment of ecosystem-service sensitivity to land-use change, Ecol. Appl., 17, 2377-2386, 2007a.

Quetier, F., Thebault, A., and Lavorel, S.: Plant traits in a state and transition framework as markers of ecosystem response to landuse change, Ecol. Monogr., 77, 33-52, 2007b.

Robson, T. M., Lavorel, S., Clement, J. C., and Le Roux, X.: Neglect of mowing and manuring leads to slower nitrogen cycling in subalpine grasslands,Soil Biol. Biochem., 39, 930-941, 2007.

Robson, T. M., Baptist, F., Clement, J. C., and Lavorel, S.: Land use in subalpine grasslands affects nitrogen cycling via changes in plant community and soil microbial uptake dynamics, J. Ecol., 98, 62-73, 2010.

Saccone, P., Morin, S., Baptist, F., Bonneville, J.-M., Colace, M.P., Domine, F., Faure, M., Geremia, R., Lochet, J., Poly, F., Lavorel, S., and Clément, J.-C.: The effects of snowpack properties and plant strategies on litter decomposition during winter in subalpine meadows, Plant Soil, 363, 215-229, 2013.

Schimel, J. P. and Clein, J. S.: Microbial response to freeze-thaw cycles in tundra and taiga soils, Soil Biol. Biochem., 28, 10611066, 1996.

Schimel, J., Balser, T. C., and Wallenstein, M.: Microbial stressresponse physiology and its implications for ecosystem function, Ecology, 88, 1386-1394, 2007.

Schirpke, U., G. Leitinger, E. Tasser, M. Schermer, M. Steinbacher, and U. Tappeiner. Multiple ecosystem services of a changing Alpine landscape: past, present and future. International Journal of Biodiversity Science, Ecosystem Services and Management, 9, 123-135, 2012.

Schmidt, S. K. and Lipson, D. A.: Microbial growth under the snow: Implications for nutrient and allelochemical availability in temperate soils, Plant Soil, 259, 1-7, 2004.

Schmidt, S. K., Costello, E. K., Nemergut, D. R., Cleveland, C. C., Reed, S. C., Weintraub, M. N., Meyer, A. F., and Martin, A. M.: Biogeochemical consequences of rapid microbial turnover and seasonal succession in soil, Ecology, 88, 1379-1385, 2007.

Stahl, V. M., Beyschlag, W., and Werner, C.: Dynamic niche sharing in dry acidic grasslands -a N-15-labeling experiment, Plant Soil, 344, 389-400, 2011.

Stark, J. M.: Nutrient Transformations, in: Methods in Ecosystem Science, edited by: Sala, O. E., Jackson, R. B., Mooney, H. A., and Howarth, R., Springer-Verlag New York, 215-234, 2000.

Stark, J. M. and Hart, S. C.: Diffusion technique for preparing salt solutions, Kjeldahl digests, and persulfate digests for nitrogen-15 analysis, Soil Sci. Soc. Am. J., 60, 1846-1855, 1996.

Steenwerth, K. L., Jackson, L. E., Calderon, F. J., Stromberg, M. R., and Scow K. M.: Soil microbial community composition and land use history in cultivated and grassland ecosystems of coastal California, Soil Biol. Biochem., 34, 1599-1611, 2002.

Strickland, M. S., Callaham, M. A., Davies, C. A., Lauber, C. L., Ramirez, K., Richter, D. D., Fierer, N., and Bradford, M. A.: Rates of in situ carbon mineralization in relation to land- 
use, microbial community and edaphic characteristics, Soil Biol. Biochem., 4, 260-269, 2010.

Van der Heijden, M. G. A., Bardgett, R. D., and van Straalen, N. M.: The unseen majority: soil microbes as drivers of plant diversity and productivity in terrestrial ecosystems, Ecol. Lett., 11, 296310,2008

Viard-Cretat, F., Gallet, C., Lefebvre, M., and Lavorel, S.: A leachate a day keeps the seedlings away: mowing and the inhibitory effects of Festuca paniculata in subalpine grasslands, Ann. Botany, 103, 1271-1278, 2009.

Weigelt, A., Bol, R., and Bardgett, R. D.: Preferential uptake of soil nitrogen forms by grassland plant species, Oecologia, 142, 627$635,2005$.
Werdin-Pfisterer, N. R., Kielland, K., and Boone, R. D.: Soil amino acid composition across a boreal forest successional sequence, Soil Biol. Biochem., 41, 1210-1220, 2009.

Zeller, V., Bahn, M., Aichner, M., and Tappeiner, U.: Impact of land-use change on nitrogen mineralization in subalpine grasslands in the Southern Alps, Biol. Fert. Soils, 31, 441-448, 2000.

Zhu, J. X., Yang W. Q., and He X. H.: Temporal Dynamics of Abiotic and Biotic Factors on Leaf Litter of Three Plant Species in Relation to Decomposition Rate along a Subalpine Elevation Gradient, Plos One, 8, doi:10.1371/journal.pone.0062073, 2013. 